Journal of Zhejiang University-SCIENCE B (Biomedicine \& Biotechnology)

ISSN 1673-1581 (Print); ISSN 1862-1783 (Online)

www.zju.edu.cn/jzus; www.springerlink.com

E-mail: jzus@zju.edu.cn

Review:

\title{
Pathogenetic and prognostic roles of bloodborne fibrocytes in asthma
}

\author{
Sabrina MATTOLI \\ (Scientific Direction and Project Management, Avail Biomedical Research Institute, Postfach 102, CH-4010 Basel, Switzerland) \\ E-mail: smattoli@avail-research.com \\ Received May 26, 2015; Revision accepted July 25, 2015; Crosschecked July 8, 2015
}

\begin{abstract}
Bloodborne fibrocytes are cells mobilized from the bone marrow, which express surface antigens commonly ascribed to hematopoietic progenitors and have phenotypic and functional characteristics similar to those of immature mesenchymal cells. They exhibit predominant proinflammatory or profibrotic activities at tissue sites, depending on the host's response to environmental insults and on the characteristics of the cell infiltrate and cytokine milieu. In patients with allergic asthma, fibrocytes egress from the bone marrow and are recruited into the airways after every allergen exposure and during viral infections. Recruited fibrocytes amplify the inflammatory responses driven by T helper type 2 lymphokines and favor viral replication and further inflammation on respiratory virus infections. Persistently elevated blood fibrocyte counts and persisting airway fibrocytosis are present in patients with chronically undertreated or corticosteroid-insensitive asthma, and are linked to an enhanced risk of adverse outcomes because of the major involvement of fibrocytes in the development of structural abnormalities that lead to chronic airflow obstruction in these patients. Consequently, blood fibrocyte count is an emerging biomarker of asthma control and disease progression and its clinical applicability as a new outcome measure deserves further evaluation in large clinical trials.
\end{abstract}

Key words: Airway remodeling, Asthma, Biomarker, Chronic inflammation, Fibrocyte doi:10.1631/jzus.B1500129 Document code: A CLC number: R562.2 $2^{+}$

\section{Introduction}

Asthma is a chronic pulmonary disorder with a clinical course characterized by episodes of bronchial constriction of various durations and intensity, which occur spontaneously, without an identifiable trigger, or as a result of allergen exposure and viral infections in individuals predisposed to the clinical expression of the disease because of complex interactions between genetic or epigenetic factors and the environment (National Asthma Education and Prevention Program, 2007; Bellini et al., 2013; Olin and Wechsler, 2014; Global Initiative for Asthma, 2015). On a global scale, over 300 million subjects suffer from asthma and 250000 die from this disease every year (Pearce et al., 2007; To et al., 2012; Zhang et al.,

(6) ORCID: Sabrina MATTOLI, http://orcid.org/0000-0002-6866-604X (C) Zhejiang University and Springer-Verlag Berlin Heidelberg 2015
2013). It has a profound societal impact because of the high healthcare costs, school absenteeism, loss of work productivity, and poor patient quality of life (To et al., 2012). Its prevalence is increasing (Pearce et al., 2007; To et al., 2012; Zhang et al., 2014; Huang et al., 2015) and there are no effective strategies to prevent the onset of the disease or therapies to cure it (Guilbert et al., 2006; Martinez, 2011). The management of asthma therefore aims to achieve good control of symptoms and to minimize the risk of future exacerbations, the development of chronic airflow obstruction, and the occurrence of treatment side effects (Reddel et al., 2009; Global Initiative for Asthma, 2015).

The currently recommended therapeutic approach involving regular anti-inflammatory treatment with inhaled corticosteroids and the use of bronchodilators is effective in most patients with asthma, but more than $15 \%$ of the asthmatic individuals worldwide are undertreated or have a severe disease refractory to 
currently available therapies despite the intensive treatment, including the use of high doses of inhaled corticosteroids and systemic corticosteroids in combination with long-acting bronchodilators and add-on medications (Olin and Wechsler, 2014; Zhang et al., 2014; Global Initiative for Asthma, 2015). These patients with poor asthma control have persisting airway inflammation and are at increased risk of acute exacerbations and of adverse outcomes resulting from the development of irreversible structural alterations of the bronchial wall, such as subepithelial fibrosis, bronchial smooth muscle (SM) hypertrophy/hyperplasia and increased density of myofibroblasts and other non-SM contractile cells in the airways (Holgate, 2008; Pascual and Peters, 2009; Bai, 2010; Halwani et al., 2010; Durrani et al., 2011; Olin and Wechsler, 2014). In the next sections, I discuss the major involvement of bloodborne fibrocytes (Fcs) in the amplification of immune responses and progression of structural changes, and describe the potential advantages of using blood Fcs count as a biomarker to monitor the level of asthma control and recognize patients at high risk of future adverse outcomes.

\section{Background information on Fc identifica- tion and isolation}

Bloodborne Fcs are $\mathrm{CD} 45^{+} \mathrm{CD} 45 \mathrm{RO}^{+} \mathrm{CD} 34^{+}$ HLA-DR ${ }^{+} \mathrm{CD} 11 \mathrm{~b}^{+} \mathrm{CD} 13^{+}$cells (Bucala et al., 1994; Chesney et al., 1998) that originate in the bone marrow (BM) (Mori et al., 2005; Suga et al., 2014). They circulate as a part of the peripheral blood mononuclear cell (PBMC) subpopulation of total leukocytes (Bucala et al., 1994; Chesney et al., 1998; Abe et al., 2001; Bianchetti et al., 2014) and have light scatter features on flow cytometry analysis similar to those of circulating myeloid dendritic cells (mDCs) and some myeloid progenitor cells (mPCs) (Bianchetti et al., 2014). They constitutively express some of the receptors that mediate the trafficking of other BMderived CD34 ${ }^{+}$PCs, mDCs, and eosinophils (Els) in asthma (Bellini et al., 2013; Mattoli, 2015), such as the C-X-C motif chemokine receptor 4 (CXCR4) (Abe et al., 2001), the C-C motif chemokine receptors (CCRs) CCR3, CCR5, and CCR7 (Abe et al., 2001; Isgrò et al., 2013a), and the receptor for interleukin (IL)-33 suppressor of tumorigenicity 2 (ST2) (Bian- chetti et al., 2012a). Fcs have antigen-presenting function (Chesney et al., 1997; Isgrò et al., 2013b) and proinflammatory activities (Chesney et al., 1998; Bellini et al., 2012; Isgrò et al., 2013a; 2013b) relevant to asthma (Mattoli, 2015). They participate in extracellular matrix (EM) remodeling through the production of some of the collagens and noncollagenous EM components synthesized in larger quantities by fibroblasts (Bucala et al., 1994; Chesney et al., 1998; Abe et al., 2001; Bianchetti et al., 2012b), and are also involved in collagen uptake and degradation (Bianchetti et al., 2012b). These cells can exhibit predominant proinflammatory activities or predominant profibrotic properties at tissue sites, depending on the host's response to diverse environmental insults (allergens, viruses, irritants) (Isgrò et al., 2013b) and on the characteristics of the local cell infiltrate and cytokine milieu (Bellini et al., 2012; Sazuka et al., 2014). Similarly to other cells with combined antigenpresenting function and mesenchymal cell-like features (Muñoz-Fernández et al., 2006; Saada et al., 2006), they acquire a myofibroblast-like phenotype in vitro and at the tissue sites because of the expression of adhesion molecules also present on the surface of these cells (Bianchetti et al., 2012b) and the inducible synthesis of the intracellular contractile protein $\alpha$-smooth muscle actin ( $\alpha$-SMA) (Abe et al., 2001; Schmidt et al., 2003; Mori et al., 2005; Saunders et al., 2009).

As extensively discussed in a recent review (Mattoli, 2015), most of the studies that have evaluated the pathogenetic role of Fcs in asthma have adopted the method originally described by the group that discovered these cells (Bucala et al., 1994; Chesney et al., 1998) to identify Fcs in the peripheral blood and at tissue sites. Such method consists in the detection of cells coexpressing CD34 on the cell surface and type I collagen (COL1) in the cytoplasm by using specific antibodies and accurately distinguishes circulating Fes from any other circulating cells, including the subpopulation of $\mathrm{CD} 45^{+} \mathrm{CD} 34^{-} \mathrm{CD} 11 \mathrm{~b}^{+}$ $\mathrm{CD}_{13}{ }^{+}$monocytes that non-specifically bind antibodies against COL1 because they express receptors with a collagenous domain identical to that present in all secreted fibrillar collagens and intracellular collagen precursor protein (procollagens) (Isgrò et al., 2013a). This method also serves to distinguish Fcs from other cells at tissue sites because COL1- 
producing fibroblasts and macrophages containing phagocytized fragments of collagen in the cytoplasm are CD34-negative. Its major limitation is that it precludes the isolation of a viable population of Fcs for functional analyses, because intracellular staining for COL1 requires prior cell fixation and permeabilization. To address this issue, novel multiple parameter approaches have been developed that allow for the identification and sorting of a pure population of circulating and tissue Fcs by flow cytometry on the basis of the coexpression at high levels on the cell surface of CD45/CD45RO, CD34, CD11b, and CD13 (Bianchetti et al., 2012a; 2014; Isgrò et al., 2013a; 2013b), which is a distinctive feature of Fcs (Bucala et al., 1994; Chesney et al., 1998; Isgrò et al., 2013b; Bianchetti et al., 2014). Taking advantage of these technical improvements, it has been possible to uncover many functional properties of isolated Fcs and improve our understanding of the molecular mechanisms and signaling pathways involved in their trafficking and activation in asthma (Bellini et al., 2012; Bianchetti et al., 2012a; Isgrò et al., 2013a; 2013b), as discussed below.

\section{Pathogenetic roles in asthma}

\subsection{Amplification of inflammation induced by allergen exposure and viral infections}

Fcs have an antigen-presenting function in vitro (Chesney et al., 1997; Isgrò et al., 2013b) and it has been reported (Chesney et al., 1997) that a small fraction of antigen-pulsed Fcs can localize to regional lymph nodes and prime naive $\mathrm{T}$ cells after intradermal injection in mice. However, the results of a study in a mouse model of allergic asthma do not support the ability of Fcs to induce immunological responses to allergens mediated by $\mathrm{T}$ helper type 2 lymphocytes (TH2Ls) (Schmidt et al., 2003). More importantly, they indicate that the mobilization of Fcs from the $\mathrm{BM}$ and their recruitment to the bronchial wall only occur after repeated exposure to the allergen and following the establishment of a TH2L-driven inflammatory response (Schmidt et al., 2003). Fcs may instead play a major role in the recall phase of the allergic response, given that in allergic asthmatics every allergen exposure is associated with a progressive increase in the density of these cells in the bronchial mucosa from 4 to $24 \mathrm{~h}$ post allergen inhalation (Schmidt et al., 2003). In support of the ability of Fcs to amplify TH2L-driven inflammatory responses in the airways, a recent study from my laboratories has demonstrated that circulating Fcs and $\mathrm{mDCs}$ from allergic asthmatics similarly induce the proliferation of autologous circulating memory $\mathrm{CD} 4{ }^{+}$ THLs and the predominant release of the TH2 cytokines IL-4 and IL-5 from effector CD4 $4^{+}$THLs when pulsed with the clinically relevant allergen (Isgrò et al., 2013b).

Viral infections are considered important triggers of asthma exacerbations, particularly in allergic individuals (Murray et al., 2004; Friedlander and Busse, 2005; Khetsuriani et al., 2007). Fcs from allergic asthmatics can be infected with one of the rhinoviruses mostly implicated in asthma exacerbations (Isgrò et al., 2013b). Infected Fcs allow prolonged viral replication and produce elevated amounts of cytokines that are known to increase the imbalance between airway $\mathrm{TH} 2 \mathrm{~L}$ and regulatory $\mathrm{TL}$ in allergic asthmatic patients and that worsen bronchial inflammation (Isgrò et al., 2013b). Through these mechanisms persistent infiltration of the airways with Fcs may impede the rapid resolution of viral infections and increase the risk of acute exacerbations.

\subsection{Contribution to airway remodeling in persis- tent asthma}

The histopathologic abnormalities most frequently observed in the airways of patients with persistent asthma include a chronic inflammatory infiltrate of the bronchial mucosa and various structural alterations poorly responsive to available therapies, commonly referred to by the term "airway remodeling" (Pascual and Peters, 2009; Durrani et al., 2011). Some of the remodeling lesions are not specific as they reflect persistent tissue injury or defective repair (or both), but the thickening of the lamina reticularis and the increase in the $\mathrm{SM} /$ contractile mass are characteristic structural alterations of asthma (Jeffery, 2004). These abnormalities are more prominent in patients who have inadequately controlled disease and frequent clinical exacerbations and may cause irreversible airway narrowing, with progressive deterioration of lung function (Pascual and Peters, 2009; Durrani et al., 2011). 
The thickening of the lamina reticularis is considered a form of subepithelial fibrosis as it reflects increased local production of COL1, type III collagen (COL3), type $\mathrm{V}$ collagen (COL5), and non-collagenous EM molecules such as hyaluronan, perlecan, versican, and fibronectin (Roberts, 1995; Huang et al., 1999; Pini et al., 2007). Fcs from asthmatic individuals are important and selective sources of these EM components (Bellini et al., 2012) (Fig. 1) and contribute to increase the contractile mass as they acquire a myofibroblast-like phenotype in the bronchial mucosa (Schmidt et al., 2003; Nihlberg et al., 2006; Saunders et al., 2009) and infiltrate the underlying bronchial SM bundle (Saunders et al., 2009) (Fig. 1). The density of Fes in the lamina propria directly correlates with the level of disease severity (Saunders et al., 2009) and the thickness of the fibrotic area beneath the epithelium (Nihlberg et al., 2006). The magnitude of the $\mathrm{Fc}$ infiltrate in the airways is more marked in allergic asthmatics who are experiencing disease worsening following exposure to allergens to which they are sensitized, and in patients with poorly controlled/treatment-resistant asthma, irrespective of their atopic status, as compared to patients with controlled disease (Schmidt et al., 2003; Saunders et al., 2009). In these cases, an appreciable number of Fcs which have recently migrated toward the bronchial epithelium from the bloodstream can also be found in induced sputum (Bellini et al., 2012) and their number correlates with the frequency of symptoms that require rescue medication with bronchodilators (Bellini et al., 2013). Thus, Fcs may contribute to the progression of fibrotic alterations every time there is a lack of asthma control and their effects persist as long as asthma control is not reachieved. Direct evidence of the contribution of Fcs to airway remodeling has been provided by tracking experiments in a mouse model of chronic allergic asthma with airway remodeling induced by repeated allergen exposures (Schmidt et al., 2003; Schmidt and Mattoli, 2013) and by assessing the effects of soluble factors present in the sputum of asthmatic patients on autologous circulating Fcs, including their migration, expression of the contractile protein $\alpha$-SMA, and ability to release asthma-relevant EM molecules, in relation to the clinical characteristics and therapeutic responsiveness (Isgrò et al., 2013a). Moreover, in asthmatics with chronic bronchial obstruction, the numbers of circulating Fcs correlate with the previously recorded annual decline in lung function (Wang et al., 2008), suggesting that these cells may have contributed to generate irreversible alterations of the bronchial structure in such individuals.

\subsection{Factors regulating $\mathrm{Fc}$ trafficking and activation}

In asthmatic individuals, elevated numbers of Fcs in the peripheral blood are always associated with the presence of ongoing airway inflammation (Saunders et al., 2009; Bellini et al., 2012; Isgrò et al., 2013b). The mechanisms involved in the egress of Fcs from the BM are likely similar to those described for the entire population of $\mathrm{CD} 45^{+} \mathrm{CD} 34^{+} \mathrm{PCs}$ in allergic asthmatics with ongoing airway inflammation (Sehmi et al., 2003; Dorman et al., 2005). Thus, disruption of the binding of CXCR4 to its ligand (CXCL12, formerly known as stromal cell-derived factor $1 \alpha$ ) produced by stromal BM cells, the upregulation of the expression of chemokine receptors on Fcs, and the presence of increased concentrations of the ligands for these receptors in the peripheral blood may facilitate the migration of Fcs into the circulation (Fig. 1). The recruitment of Fcs from the blood stream to the inflamed bronchial mucosa is largely mediated by chemokines and danger molecules produced by the bronchial epithelium (Bellini et al., 2013; Mattoli, 2015), particularly the CCR3/CCR5 ligands CCL5, CCL11 and CCL24, CXCL12, and IL-33 (Fig. 1). Notably, the expression of CCR3, CCR5, and ST2 is highly upregulated on the surface of circulating Fcs from patients with treatment-resistant severe asthma or suffering from acute disease exacerbations in comparison with the circulating cells from patients with adequately-controlled disease and normal individuals (Isgrò et al., 2013a; Bianchetti et al., 2012a). Moreover, the sputum fluid phase from patients with treatment-resistant severe asthma, but not that from patients with adequately-controlled disease, has a strong chemotactic effect on autologous circulating Fcs, and over $50 \%$ of this chemotactic activity is attributable to the combined presence of high amounts of CCL5, CCL11, and CCL24 (Isgrò et al., 2013b). Since Fcs express CCR7 (Abe et al., 2001), the CCR7 ligands CCL19 and CCL21 (also known as secondary lymphoid cytokine) may potentially 


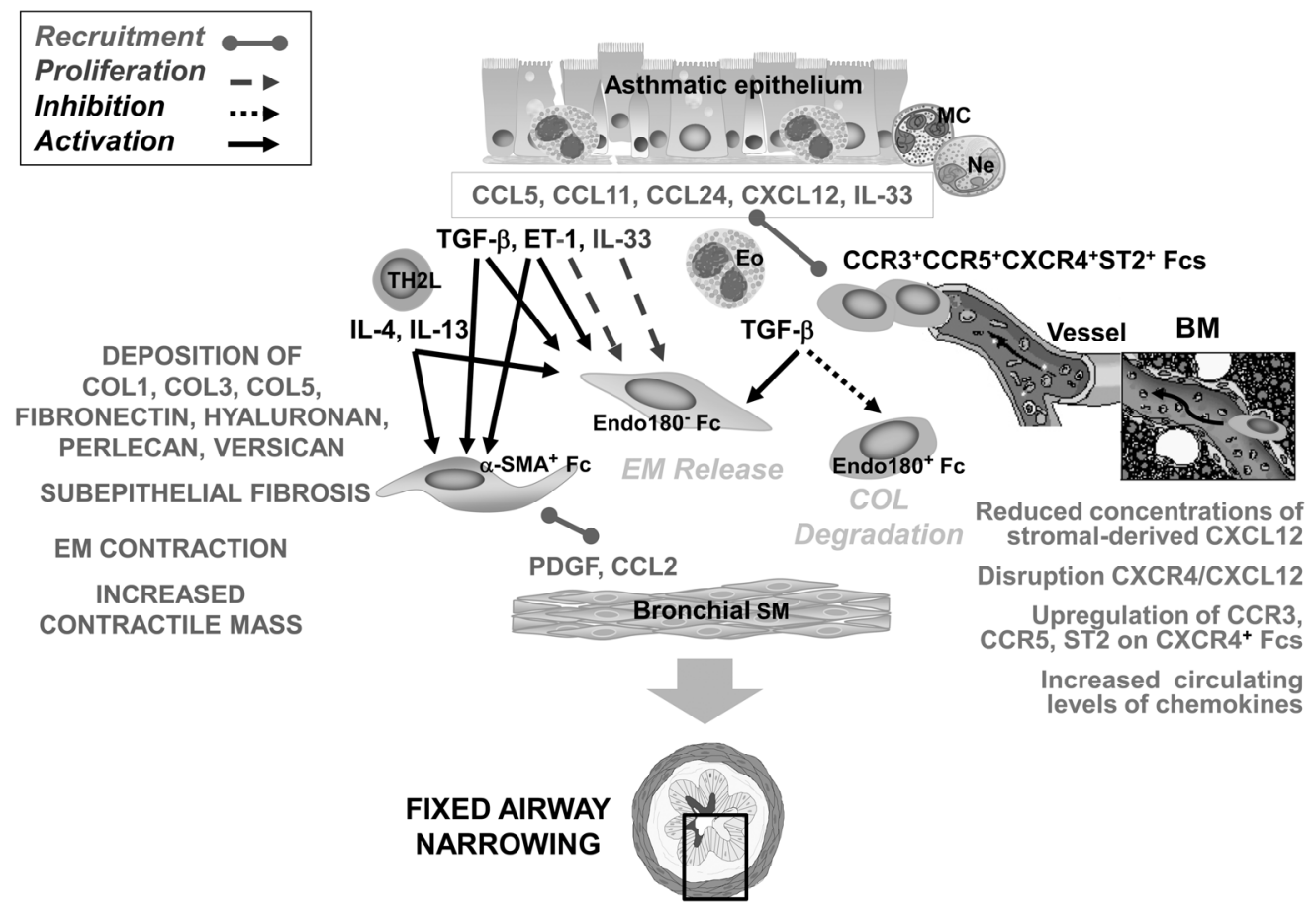

Fig. 1 Schematic illustration of the main molecular mechanisms and signaling pathways through which fibrocytes are mobilized and participate in the remodeling of the bronchial structure in inadequately treated asthma with persisting inflammation

$\alpha$-SMA: $\alpha$-smooth muscle actin; BM: bone marrow; CCL: C-C motif chemokine ligand; CCR: C-C motif chemokine receptor; COL: collagen type; CXCL: C-X-C motif chemokine ligand; CXCR: C-X-C motif chemokine receptor; EM: extracellular matrix; Eo: eosinophil; ET-1: endothelin-1; Fc: fibrocyte; IL: interleukin; MC: mast cell; Ne: neutrophil; SM: smooth muscle; TGF- $\beta$ : transforming growth factor- $\beta$; TH2L: T helper type 2 lymphocyte; ST2: suppressor of tumorigenicity 2. Adapted from Bellini et al. (2013), under the terms of the Creative Commons Attribution License, which permits unrestricted use, distribution, and reproduction in any medium, provided the original work is properly cited (Copyright $(C) 2013$ Bellini, A., Schmidt, M., Mattoli, S.)

contribute to the airway recruitment of these cells, albeit only to a small extent, as suggested by blocking experiments in an animal model of chronic allergic asthma with induced airway remodeling (Mattoli, 2006) and in vitro experiments with Fes from asthmatic patients (Wang et al., 2015). Epithelial cellderived endothelin-1 (ET-1) contributes to the expansion of the population of recruited Fcs in concert with IL-33 (Schmidt et al., 2003; Bianchetti et al., 2012a; Bellini et al., 2013) (Fig. 1). ET-1 and transforming growth factor- $\beta$ (TGF- $\beta$ ) are potent inducers of $\alpha$-SMA expression in these cells, and the activation of signaling from TGF- $\beta$ also strongly promotes the profibrotic function of Fes infiltrating the bronchial mucosa by increasing their production of EM components and by inhibiting the uptake and degradation of collagenous proteins via the Endo180-mediated pathway (Mattoli, 2006; 2015; Bellini et al., 2013) (Fig. 1).

TH2Ls are major drivers of airway inflammation in asthma and produce lymphokines that promote the contractility and profibrotic function of Fcs (Mattoli, 2015), particularly IL-4 and IL-13 (Bellini et al., 2012) (Fig. 1). Studies performed using Fcs isolated from long-term cultures of PBMCs and cultured SM cells (Saunders et al., 2009; Singh et al., 2014) have also suggested that an enhanced release of platelet-derived growth factor (PDGF) and CCL2 from the bronchial $\mathrm{SM}$ in asthma may explain the migration of Fcs that have acquired the expression of $\alpha$-SMA toward the SM bundle in vivo (Fig. 1). However, the observed chemotactic activities were modest and the receptor 
for CCL2, CCR2, was not expressed at high levels on the surface of tested Fcs.

Further investigation of the mechanisms involved in the mobilization and local activation of Fcs in asthma is of paramount importance. Considering that none of the currently approved pharmacological interventions block the progression of structural changes nor reverse them (Royce and Tang, 2009; Durrani et al., 2011), inhibition of Fc trafficking and function in patients whose disease is not adequately controlled with currently available therapies may greatly reduce the overall incidence of adverse outcomes in asthma and the associated healthcare costs. The reader is referred to a recent review (Mattoli, 2015) where I identified potential therapeutic candidates and future research directions on the basis of the mechanisms described above and schematically illustrated in Fig. 1.

\section{Prognostic roles in asthma}

All the available studies consistently indicate that the numbers of circulating Fcs are very low in normal subjects (Table 1) and that these cells are rarely detected in the bronchial mucosa of healthy individuals (Nihlberg et al., 2006; Saunders et al., 2009; Wang et al., 2015) or in their induced sputum (Bellini et al., 2012) and bronchoalveolar lavage (Nihlberg et al., 2006). In asthmatic patients, the numbers of circulating Fes are in the normal range values when their disease, irrespective of its severity, is adequately controlled by the treatment they are receiving (Saunders et al., 2009; Bianchetti et al., 2012a; 2014) (Table 1). Greatly elevated blood Fc numbers are detectable in patients experiencing a spontaneous asthma exacerbation (Bellini et al., 2012; Isgrò et al., 2013a; Wang et al., 2015) and in patients with treatment-refractory severe disease (Saunders et al., 2009; Bianchetti et al., 2012a; 2014) or "chronic obstructive asthma" (Wang et al., 2008; 2015), whose disease is scarcely controlled in spite of the intensive treatment with high doses of inhaled corticosteroids or oral corticosteroids in combination with bronchodilators (Table 1). Elevated numbers of circulating Fcs are consistently associated with the presence of airway (Saunders et al., 2009) or sputum fibrocytosis (Bellini et al., 2012) and ongoing inflammation, as reflected by sputum eosinophilia (Saunders et al., 2009; Bellini et al., 2012) and increased concentrations of proinflammatory cytokines and chemokines in the sputum fluid phase (Bellini et al., 2012; Isgrò et al., 2013b). Taken together, these observations and the studies on the pathogenetic role of Fcs in asthma discussed above clearly indicate that blood fibrocyte count is an easily accessible biomarker of asthma control and disease progression and that it may be potentially employed to monitor the adequacy of treatment, recognize patients at high risk of future adverse outcomes, and test the efficacy of new therapeutic candidates in these individuals. It offers potential advantages in comparison with existing biomarkers of asthma outcome (Szefler et al., 2012) because the enumeration of circulating Fcs requires minimally invasive procedures and high blood Fc counts indicate the presence of inflammatory and structural alterations that are currently detectable in a minimally invasive manner only by performing a cellular analysis of induced sputum together with high-resolution computed tomography (Mattoli, 2015).

In spite of the many promising observations, a proper evaluation of blood $\mathrm{Fc}$ count as a prognostic biomarker in asthma has long been precluded by the absence of a reliable assay with clinical applicability (Bianchetti et al., 2014). Most of the studies listed in Table 1 actually used methods that require PBMC isolation and further manipulation of isolated cells. Because of the unpredictable cell loss during blood sample processing, these methods do not allow for an accurate and reproducible enumeration of circulating Fcs and cannot be used at large scale. However, the recently developed multiparameter flow cytometry assay for direct Fc enumeration in the whole blood with a single instrument (Bianchetti et al., 2014) (Table 1) has been standardized and optimized for possible use in clinical practice and in multicenter clinical trials. It provides accurate and reproducible measures (Bianchetti et al., 2014) and can be employed to evaluate in larger clinical studies the validity and utility of blood Fc count as a prognostic biomarker and new outcome measure in asthma (Mattoli, 2015). 
Table 1 Circulating fibrocytes in asthma

\begin{tabular}{|c|c|c|c|}
\hline Study & Subject & $\begin{array}{l}\text { Fibrocyte source and } \\
\text { cell analysis }\end{array}$ & Fibrocyte number or percentage \\
\hline $\begin{array}{l}\text { Wang } \\
\text { et al., } 2008\end{array}$ & $\begin{array}{l}11 \text { patients with "chronic } \\
\text { obstructive asthma"; } \\
9 \text { asthmatic patients without } \\
\text { airflow obstruction; } \\
10 \text { normal subjects }\end{array}$ & $\begin{array}{l}\text { PBMC-derived non- } \\
\text { adherent non T cells; } \\
\text { Flow cytometry }\end{array}$ & $\begin{array}{l}\text { Significant increase }(P<0.001)(\text { mean } \pm \text { SEM }) \text { of CD } 45^{+} \mathrm{CD} 34^{+} \mathrm{COL} 1^{+} \\
\text {cells in patients with chronic obstructive asthma }((27.6 \pm 3.2) \%) \text { in } \\
\text { comparison with asthmatic patients without airflow obstruction } \\
((6.4 \pm 1.1) \%) \text { and normal subjects }((6.5 \pm 1.0) \%) \text {; no significant } \\
\text { differences between asthmatic patients without airflow obstruction } \\
\text { and healthy controls }\end{array}$ \\
\hline $\begin{array}{l}\text { Saunders } \\
\text { et al., } 2009\end{array}$ & $\begin{array}{l}12 \text { patients with severe } \\
\text { treatment-refractory } \\
\text { asthma (airflow obstruc- } \\
\text { tion and sputum eosino- } \\
\text { philia demonstrated); } \\
12 \text { patients with non-severe } \\
\text { asthma; } \\
13 \text { healthy controls }\end{array}$ & $\begin{array}{l}\text { PBMCs; } \\
\text { Flow cytometry }\end{array}$ & $\begin{array}{l}\text { Median number (interquartile range) of } \mathrm{CD} 45^{+} \mathrm{CD} 34^{+} \mathrm{COL} 1^{+} \text {cells } \\
\left(\times 10^{4} / \mathrm{ml} \text { blood): } 1.4(2.6) \text { in patients with severe treatment- }\right. \\
\text { refractory asthma versus } 1.0(3.1) \text { in patients with non-severe } \\
\text { asthma and } 0.4(1.0) \text { in healthy controls }(P<0.005) \text {; no significant } \\
\text { differences between patients with non-severe asthma and healthy } \\
\text { controls }\end{array}$ \\
\hline $\begin{array}{l}\text { Bellini } \\
\text { et al., } 2012\end{array}$ & $\begin{array}{l}12 \text { patients with asthma } \\
\text { exacerbation (airflow ob- } \\
\text { struction and sputum eo- } \\
\text { sinophilia demonstrated); } \\
8 \text { healthy controls }\end{array}$ & $\begin{array}{l}\text { Total CD } 45^{+} \text {leukocytes; } \\
\text { Double-platform flow } \\
\text { cytometry assay and } \\
\text { double in-situ } \\
\text { hybridization and } \\
\text { immunohistochemical } \\
\text { analysis of cytospins }\end{array}$ & $\begin{array}{l}\text { Median number (range values) of } \mathrm{CD} 34^{+} \mathrm{COL}^{+} \mathrm{COL} 1 \mathrm{mRNA}^{+} \text {cells } \\
\left(\times 10^{4} / \mathrm{ml} \text { blood }\right): 20.2(12.2-33.4) \text { in patients with asthma exacer- } \\
\text { bation versus } 0.37(0.14-0.82) \text { in healthy controls }(P<0.001)\end{array}$ \\
\hline $\begin{array}{l}\text { Bianchetti } \\
\text { et al., 2012a }\end{array}$ & $\begin{array}{l}9 \text { patients with asthma } \\
\text { exacerbation; } \\
14 \text { non-asthmatic individuals } \\
\text { (7 atopic) }\end{array}$ & $\begin{array}{l}\text { PBMCs; } \\
\text { Flow cytometry }\end{array}$ & $\begin{array}{l}\text { Median number (interquartile range) of } \mathrm{CD} 45 \mathrm{RO}^{+} \mathrm{CD} 34^{+} \mathrm{CD} 11 \mathrm{~b}^{+} \mathrm{CD} 13 \mathrm{~b}^{+} \\
\mathrm{COL} 1^{+} \text {cells }\left(\times 10^{4} / \mathrm{ml} \text { blood): } 6.9(5.3) \text { in patients with asthma ex- }\right. \\
\text { acerbation versus } 0.8(1.6) \text { in healthy controls }(P<0.01)\end{array}$ \\
\hline $\begin{array}{l}\text { Isgrò } \\
\text { et al., 2013b }\end{array}$ & $\begin{array}{l}16 \text { patients with severe } \\
\text { treatment-resistant asthma* } \\
19 \text { patients with controlled } \\
\text { treatment-responsive } \\
\text { asthma** }\end{array}$ & $\begin{array}{l}\text { PBMCs; } \\
\text { Flow cytometry }\end{array}$ & $\begin{array}{l}\text { Median number (interquartile range) of } \mathrm{CD} 45 \mathrm{RO}^{+} \mathrm{CD} 34^{+} \mathrm{CD} 11 \mathrm{~b}^{+} \\
\mathrm{CD} 13 \mathrm{~b}^{+} \mathrm{COL} 1^{+} \text {cells }\left(\times 10^{4} / \mathrm{ml} \text { blood }\right): 4.6(2.2) \text { in patients with } \\
\text { treatment-resistant asthma versus } 1.7(2.1) \text { in controlled treatment- } \\
\text { responsive asthma }(P<0.01)\end{array}$ \\
\hline $\begin{array}{l}\text { Bianchetti } \\
\text { et al., } 2014\end{array}$ & $\begin{array}{l}16 \text { patients with partly } \\
\text { controlled/uncontrolled } \\
\text { treatment-resistant asthma; } \\
19 \text { patients with controlled } \\
\text { asthma**; } \\
9 \text { patients with transiently } \\
\text { uncontrolled asthma be- } \\
\text { cause of temporary dis- } \\
\text { ease worsening with re- } \\
\text { ceived treatment; } \\
14 \text { healthy controls matched } \\
\text { for age and atopic status }\end{array}$ & $\begin{array}{l}\text { Whole blood; } \\
\text { Single platform flow } \\
\text { cytometry assay }\end{array}$ & $\begin{array}{l}\text { Median number }(\mathrm{SD}) \text { of viable } \mathrm{CD} 45^{+}[\mathrm{CD} 3 / \mathrm{CD} 19 / \mathrm{CD} 20 / \mathrm{CRTH} 2]^{-} \\
\mathrm{CD} 16^{-} \mathrm{CD} 115^{-} \mathrm{CD} 11 \mathrm{~b}^{+} \mathrm{CD} 34^{+} \text {cells (per } \mu 1 \text { blood): } 9.41(5.92) \text { in } \\
\text { healthy controls versus } 14.05(8.28) \text { in patients with controlled } \\
\text { asthma }(P>0.05) \text { versus } 30.42(8.84) \text { in patients with transiently } \\
\text { uncontrolled asthma }(P<0.01) \text { versus } 22.46(9.65) \text { in patients with } \\
\text { partly controlled/uncontrolled treatment-resistant asthma }(P<0.01) \text {; } \\
\text { Analytical validity of the assay confirmed by testing } C O L 1 \text { mRNA } \\
\text { expression and inducibility of } \alpha \text {-SMA expression in response to } \\
\text { ET-1 stimulation in sorted cells; } \\
\text { Cutoff of } 13 \text { fibrocytes (per } \mu 1 \text { blood) distinguishes normal from } \\
\text { asthmatic individuals and a cutoff of } 18 \text { fibrocytes (per } \mu 1 \text { blood) } \\
\text { distinguishes patients with well-controlled asthma from patients } \\
\text { with uncontrolled or treatment-resistant disease. High reproduci- } \\
\text { bility over time of measures in healthy controls and patients with } \\
\text { stable conditions (ICC }=0.939 \text {; Pearson } r 0.995, P<0.001)\end{array}$ \\
\hline $\begin{array}{l}\text { Wang } \\
\text { et al., } 2015\end{array}$ & $\begin{array}{l}14 \text { patients with asthma } \\
\text { exacerbation; } \\
14 \text { patients with "chronic } \\
\text { obstructive asthma"; } \\
14 \text { asthmatic patients with } \\
\text { normal pulmonary } \\
\text { function; } \\
11 \text { healthy controls }\end{array}$ & $\begin{array}{l}\text { PBMC-derived non- } \\
\text { adherent non T cells; } \\
\text { Flow cytometry }\end{array}$ & $\begin{array}{l}\text { Mean (SEM) percentage of } \mathrm{CD} 45^{+} \mathrm{CD} 34^{+} \mathrm{COL} 1^{+} \text {cells significantly } \\
\text { higher in patients with asthma exacerbation and patients with } \\
\text { chronic obstructive asthma versus the other groups }(P<0.001) \text {; } \\
\left.\text { Significant reduction in } \mathrm{CD} 45^{+} \mathrm{CD} 34^{+} \mathrm{COL} 1^{+} \text {cells (mean } \pm \mathrm{SEM}\right) \text { in } \\
\text { patients with asthma exacerbation after recovery (from }(10.1 \pm 1.8) \% \\
\text { to }(5.8 \pm 0.7) \% ; P<0.05)\end{array}$ \\
\hline
\end{tabular}

\footnotetext{
* Features of partly controlled/uncontrolled asthma over 2 months and emergency room visit for asthma exacerbation in the past year in spite of intensive treatment with high doses inhaled corticosteroids and/or oral corticosteroids in combination with bronchodilators: prebronchodilator forced expiratory volume in $1 \mathrm{~s}<80 \%$ of predicted normal; daytime symptoms $>2 \mathrm{~d}$ per week; any limitations of activities because of symptoms; night-time symptoms or on awakening at least once per week; reliever use $>2 \mathrm{~d}$ per week; $\geq 3$ of the above features per week. ${ }^{* *}$ No features of partly controlled/uncontrolled asthma over the previous 2 months and no emergency room visit for asthma exacerbation in the past year. COL1: type I collagen; $\alpha$-SMA: $\alpha$-smooth muscle actin; ET-1: endothelin-1; ICC: intraclass correlation coefficient; PBMC: peripheral blood mononuclear cell; SD: standard deviation; SEM: standard error of the mean
} 


\section{Concluding remarks}

In asthma, the assessment of disease control is essential for monitoring the individual response to available therapies (Reddel et al., 2009; Global Initiative for Asthma, 2015) and for testing the efficacy of new therapeutic candidates (Reddel et al., 2009). Blood Fc count is an emerging biomarker of asthma control, because elevated numbers of circulating Fcs reflect ongoing airway inflammation and distinguish patients with adequately controlled disease from those whose asthma is chronically undertreated or resistant to available therapies. Blood Fc count is also an emerging biomarker of disease progression because elevated numbers of circulating Fcs reflect ongoing airway remodeling. Persistently elevated blood Fc counts are associated with persisting airway fibrocytosis, which causes further structural alterations and also increases the risk of acute exacerbations by amplifying TH2L-driven inflammation after every allergen exposure and rhinovirus infection and by delaying the resolution of viral infections. For these reasons, the integration of agents targeting Fc trafficking and activation into the management strategy for patients with asthma resistant to currently available drugs may greatly reduce the future risk of acute exacerbations and adverse outcomes.

\section{Compliance with ethics guidelines}

I am founding shareholder and member of the board of AVAIL GmbH.

All cited research studies are published and the authors declared in their articles that the studies were conducted in compliance with local and international ethics guidelines.

\section{References}

Abe, R., Donnelly, S.C., Peng, T., et al., 2001. Peripheral blood fibrocytes: differentiation pathway and migration to wound sites. J. Immunol., 166(12):7556-7562. [doi:10. 4049/jimmunol.166.12.7556]

Bai, T.R., 2010. Evidence for airway remodeling in chronic asthma. Curr. Opin. Allergy Clin. Immunol., 10(1):82-86. [doi:10.1097/ACI.0b013e32833363b2]

Bellini, A., Marini, M.A., Bianchetti, L., et al., 2012. Interleukin (IL)-4, IL-13, and IL-17A differentially affect the profibrotic and proinflammatory functions of fibrocytes from asthmatic patients. Mucosal Immunol., 5(2):140-149. [doi:10.1038/mi.2011.60]

Bellini, A., Schmidt, M., Mattoli, S., 2013. Interactions between the bronchial epithelium and fibrocytes in the pathogenesis of airway remodeling in asthma. J. Epithe- lial Biol. Pharmacol., 6(1):1-10. [doi:10.2174/18750443 01306010001]

Bianchetti, L., Marini, M.A., Isgrò, M., et al., 2012a. IL-33 promotes the migration and proliferation of circulating fibrocytes from allergen-exacerbated asthma. Biochem. Biophys. Res. Commun., 426(1):116-121. [doi:10.1016/j. bbrc.2012.08.047]

Bianchetti, L., Barczyk, M., Cardoso, J., et al., 2012b. Extracellular matrix remodelling properties of human fibrocytes. J. Cell. Mol. Med., 16(3):483-495. [doi:10.1111/ j.1582-4934.2011.01344.x]

Bianchetti, L., Isgrò, M., Marini, M.A., et al., 2014. Enumeration of circulating fibrocytes for clinical use in asthma by an optimized single-platform flow cytometry assay. BBA Clin., 1:52-58. [doi:10.1016/j.bbacli.2014.06.002]

Bucala, R., Spiegel, L.A., Chesney, J., et al., 1994. Circulating fibrocytes define a new leukocyte subpopulation that mediates tissue repair. Mol. Med., 1(1):71-81.

Chesney, J., Bacher, M., Bender, A., et al., 1997. The peripheral blood fibrocyte is a potent antigen-presenting cell capable of priming naive T cells in situ. PNAS, 94(12): 6307-6312. [doi:10.1073/pnas.94.12.6307]

Chesney, J., Metz, C., Stavitsky, A.B., et al., 1998. Regulated production of type I collagen and inflammatory cytokines by peripheral blood fibrocytes. J. Immunol., 160(1): 419-425.

Dorman, S.C., Babirad, I., Post, J., et al., 2005. Progenitor egress from the bone marrow after allergen challenge: role of stromal cell-derived factor $1 \alpha$ and eotaxin. $J$. Allergy Clin. Immunol., 115(3):501-507. [doi:10.1016/j.jaci. 2004.11.017]

Durrani, S.R., Viswanathan, R.K., Busse, W.W., 2011. What effect does asthma treatment have on airway remodeling? Current perspectives. J. Allergy Clin. Immunol., 128(3): 439-448. [doi:10.1016/j.jaci.2011.06.002]

Friedlander, S.L., Busse, W.W., 2005. The role of rhinovirus in asthma exacerbations. J. Allergy Clin. Immunol., 116(2): 267-273. [doi:10.1016/j.jaci.2005.06.003]

Global Initiative for Asthma, 2015. Global Strategy for Asthma Management and Prevention. Available from http://www.ginasthma.org/local/uploads/files/GINA_ Report_2015_May 19.pdf [Accessed on 26 May 2015].

Guilbert, T.W., Morgan, W.J., Zeiger, R.S., et al., 2006. Long-term inhaled corticosteroids in preschool children at high risk for asthma. N. Engl. J. Med., 354(19): 1985-1997. [doi:10.1056/NEJMoa051378]

Halwani, R., Al-Muhsen, S., Hamid, Q., 2010. Airway remodeling in asthma. Curr. Opin. Pharmacol., 10(3): 236-245. [doi:10.1016/j.coph.2010.06.004]

Holgate, S.T., 2008. Pathogenesis of asthma. Clin. Exp. Allergy, 38(6):872-897. [doi:10.1111/j.1365-2222.2008. 02971.x]

Huang, C., Liu, W., Hu, Y., et al., 2015. Updated prevalence of asthma, allergy, and airway symptoms, a systematic review of trends over time for childhood asthma in Shanghai, China. PLoS ONE, 10(4):e0121577. [doi:10. 
1371/journal.pone.0121577]

Huang, J., Olivenstein, R., Taha, R., et al., 1999. Enhanced proteoglycan deposition in the airway wall of atopic asthmatics. Am. J. Respir. Crit. Care Med., 160(2): 725-729. [doi:10.1164/ajrccm.160.2.9809040]

Isgrò, M., Bianchetti, L., Marini, M.A., et al., 2013a. Involvement of fibrocytes in allergen-induced $\mathrm{T}$ cell responses and rhinovirus infections in asthma. Biochem. Biophys. Res. Commun., 437(3):446-451. [doi:10.1016/j. bbrc.2013.06.099]

Isgrò, M., Bianchetti, L., Marini, M.A., et al., 2013b. The C-C motif chemokine ligands CCL5, CCL11, and CCL24 induce the migration of circulating fibrocytes from patients with severe asthma. Mucosal Immunol., 6(4): 718-727. [doi:10.1038/mi.2012.109]

Jeffery, P.K., 2004. Remodeling and inflammation of bronchi in asthma and chronic obstructive pulmonary disease. Proc. Am. Thorac. Soc., 1(3):176-183. [doi:10.1513/pats. 200402-009MS]

Khetsuriani, N., Kazerouni, N.N., Erdman, D.D., et al., 2007. Prevalence of viral respiratory tract infections in children with asthma. J. Allergy Clin. Immunol., 119(2):314-321. [doi:10.1016/j.jaci.2006.08.041]

Martinez, D.M., 2011. New insights into the natural history of asthma: primary prevention on the horizon. J. Allergy Clin. Immunol., 128(5):939-945. [doi:10.1016/j.jaci.2011. 09.020]

Mattoli, S., 2006. Tissue repair in asthma: the origin of subepithelial fibroblasts and myofibroblasts. In: Chaponnier, C., Desmoulière, A., Gabbiani, G. (Eds.), Tissue Repair, Contraction and the Myofibroblasts. Landes Bioscience and Springer Science+Business Media, Georgetown, TX, p.40-46. [doi:10.1007/0-387-33650-8_5]

Mattoli, S., 2015. Involvement of fibrocytes in asthma and clinical implications. Clin. Exp. Allergy, in press. [doi:10. 1111/cea.12525]

Mori, L., Bellini, A., Stacey, M.A., et al., 2005. Fibrocytes contribute to the myofibroblast population in the wounded skin and originate from the bone marrow. Exp. Cell Res., 304(1):81-90. [doi:10.1016/j.yexcr.2004.11.011]

Muñoz-Fernández, R., Blanco, F.J., Frecha, C., et al., 2006. Follicular dendritic cells are related to bone marrow stromal cell progenitors and to myofibroblasts. J. Immunol., 177(1):280-289. [doi:10.4049/jimmunol.177.1.280]

Murray, C.S., Simpson, A., Custovic, A., 2004. Allergens, viruses, and asthma exacerbations. Proc. Am. Thorac. Soc., 1(2):99-104. [doi:10.1513/pats.2306027]

National Asthma Education and Prevention Program, 2007. Expert Panel Report 3 (EPR-3): guidelines for the diagnosis and management of asthma - summary report 2007. J. Allergy Clin. Immunol., 120(5 Suppl.):S94-S138. [doi: 10.1016/j.jaci.2007.09.029]

Nihlberg, K., Larsen, K., Hultgårdh-Nilsson, A., et al., 2006. Tissue fibrocytes in patients with mild asthma: a possible link to thickness of reticular basement membrane? Respir. Res., 7:50. [doi:10.1186/1465-9921-7-50]
Olin, J.T., Wechsler, M.E., 2014. Asthma: pathogenesis and novel drugs for treatment. $B M J, 349:$ g5517 [doi:10. 1136/bmj.g5517]

Pascual, R.M., Peters, S.P., 2009. The irreversible component of persistent asthma. J. Allergy Clin. Immunol., 124(5): 883-890. [doi:10.1016/j.jaci.2009.09.047]

Pearce, N., Ait-Khaled, N., Beasley, R., et al., 2007. Worldwide trends in the prevalence of asthma symptoms: Phase III of the International Study of Asthma and Allergies in Childhood (ISAAC). Thorax, 62(9):758-766. [doi:10. 1136/thx.2006.070169]

Pini, L., Hamid, Q., Shannon, J., et al., 2007. Differences in proteoglycans deposition in the airways of moderate and severe asthmatics. Eur. Respir. J., 29(1):71-77. [doi:10. 1183/09031936.00047905]

Reddel, H.K., Taylor, D.R., Bateman, E.D., et al., 2009. An official American Thoracic Society/European Respiratory Society statement: asthma control and exacerbations. Standardizing endpoints for clinical asthma trials and clinical practice. Am. J. Respir. Crit. Care Med., 180(1): 59-99. [doi:10.1164/rccm.200801-060ST]

Roberts, C.R., 1995. Is asthma a fibrotic disease? Chest, $\mathbf{1 0 7}$ (3 Suppl.):111S-117S. [doi:10.1378/chest.107.3_Supplement. $111 \mathrm{~S}]$

Royce, S.G., Tang, M.L., 2009. The effects of current therapies on airway remodeling in asthma and new possibilities for treatment and prevention. Curr. Mol. Pharmacol., 2(2): 169-181. [doi:10.2174/1874467210902020169]

Saada, J.I., Pinchuk, I.V., Barrera, C.A., et al., 2006. Subepithelial myofibroblasts are novel nonprofessional APCs in the human colonic mucosa. J. Immunol., 177(9): 5968-5979. [doi:10.4049/jimmunol.177.9.5968]

Saunders, R., Siddiqui, S., Kaur, D., et al., 2009. Fibrocyte localization to the airway smooth muscle is a feature of asthma. J. Allergy Clin. Immunol., 123(2):376-384. [doi:10.1016/j.jaci.2008.10.048]

Sazuka, S., Katsumo, T., Nakagawa, T., et al., 2014. Fibrocytes are involved in inflammation as well as fibrosis in the pathogenesis of Crohn's disease. Dig. Dis. Sci., 59(4): 760-768. [doi:10.1007/s10620-013-2813-8]

Schmidt, M., Mattoli, S., 2013. A mouse model for evaluating the contribution of fibrocytes and myofibroblasts to airway remodelling in allergic asthma. Methods Mol. Biol., 1032:235-255. [doi:10.1007/978-1-62703-496-8_19]

Schmidt, M., Sun, G., Stacey, M.A., et al., 2003. Identification of circulating fibrocytes as precursors of bronchial myofibroblasts in asthma. J. Immunol., 171(1):380-389. [doi:10.4049/jimmunol.171.1.380]

Sehmi, R., Dorman, S., Baatjes, A., et al., 2003. Allergeninduced fluctuation in $\mathrm{CC}$ chemokine receptor 3 expression on bone marrow $\mathrm{CD} 34^{+}$cells from asthmatic subjects: significance for mobilization of haemopoietic progenitor cells in allergic inflammation. Immunology, 109(4): 536-546. [doi:10.1046/j.1365-2567.2003.01686.x]

Singh, S.R., Sutcliffe, A., Kaur, D., et al., 2014. CCL2 release by airway smooth muscle is increased in asthma and 
promotes fibrocyte migration. Allergy, 69(9):1189-1197. [doi:10.1111/all.12444]

Suga, H., Rennert, R.C., Rodrigues, M., et al., 2014. Tracking the elusive fibrocyte: identification and characterization of collagen-producing hematopoietic lineage cells during murine wound healing. Stem Cells, 32(5):1347-1360. [doi:10.1002/stem.1648]

Szefler, S.J., Wenzel, S., Brown, R., et al., 2012. Asthma outcomes: biomarkers. J. Allergy Clin. Immunol., 129(3): S9-S23. [doi:10.1016/j.jaci.2011.12.979]

To, T., Stanojevic, S., Moores, G., et al., 2012. Global asthma prevalence in adults: findings from the cross-sectional world health survey. BMC Public Health, 12(1):204. [doi:10.1186/1471-2458-12-204]

Wang, C.H., Huang, C.D., Lin, H.C., et al., 2008. Increased circulating fibrocytes in asthma with chronic airflow obstruction. Am. J. Respir. Crit. Care Med., 178(6):583-591. [doi:10.1164/rccm.200710-1557OC]

Wang, C.H., Punde, T.H., Huang, C.D., et al., 2015. Fibrocyte trafficking in patients with chronic obstructive asthma and during an acute asthma exacerbation. J. Allergy Clin. Immunol., 135(5):1154-1162.e5. [doi:10.1016/j.jaci.2014. 09.011]

Zhang, W., Chen, X., Ma, L., et al., 2014. Epidemiology of bronchial asthma and asthma control assessment in Henan Province, China. Transl. Respir. Med., 2(1):5. [doi:10. 1186/2213-0802-2-5]

Zhang, Y.P., Li, B.Z., Huang, C., et al., 2013. Ten cities cross-sectional questionnaire survey of children asthma and other allergies in China. Chin. Sci. Bull., 58(34): 4182-4189. [doi:10.1007/s11434-013-5914-z]

\section{中文概要}

题 目: 血源性成纤维细胞在哮喘发病机制和预后中的 作用

概 要: 血源性成纤维细胞来自骨髓, 可表达一些通常造 血祖细胞属性的表面抗原，同时有和未成熟间质 细胞相似的表型和功能特征。依据机体对环境刺 激的反应和局部浸润的细胞类型及不同的细胞 因子环境, 血源性成纤维细胞可局部组织显示强 烈的促炎症活性或促纤维化活性。过敏性哮喘患 者每次遭受过敏原暴露或病毒感染时, 成纤维细 胞即从骨髓中迁出并被募集至气道组织; 而募集 的成纤维细胞可放大由 Th2 细胞因子驱使的炎症 反应, 并有利于病毒的复制, 进一步加重病毒感 染引发的炎症。在未治疗的慢性哮喘和激素不敏 感的哮喘患者中可观察到持续性外周血成纤维
细胞计数升高及气道纤维细胞浸润, 而这和不良 预后的风险增加有关。究其原因, 成纤维细胞主 要涉及气道结构异常的进展, 而后者导致患者慢 性气流受限。因此, 外周血成纤维细胞计数是一 种新发现的哮喘控制和疾病预后的生物学标记, 作为一种新的结果检测方法, 它的临床应用还需 要大样本临床研究去评估。

关键词: 气道重塑; 哮喘; 生物标记; 慢性炎症; 成纤维 细胞

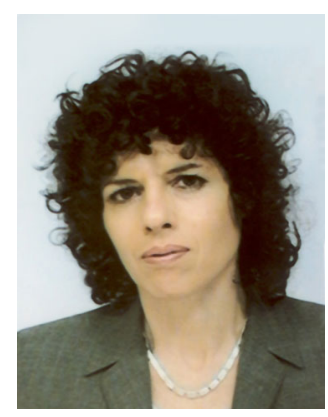

\section{Introducing editorial board member:}

Sabrina MATTOLI, MD, $\mathrm{PhD}$, an editorial board member of Journal of Zhejiang University-SCIENCE B (Biomedicine \& Biotechnology), is a board-certified pulmonologist with extensive experience in basic, translational, and clinical research. During the last 16 years, she has been the scientific director of the Avail Biomedical Research Institute, a research organization committed to improving the treatment of chronic pulmonary diseases through the discovery of new therapeutic targets and early development of therapeutic candidates (small molecules, biologics, and stem cell-derived products) more effective than the drugs currently available. She is also founder and member of the board of directors of the Avail group, works with the European Commission and several national public funding bodies in Europe as an accredited expert in research and innovation, and collaborates with various European academic institutions and professional associations in the development and conduction of continuing education programs and training courses in pharmacology and pulmonary medicine. Previously, she held various research and medical management positions at internationally accredited academic/research institutions and in the pharmaceutical industry. She has co-authored several published articles on seminal studies in the fields of asthma pathogenesis and biomarker discovery and validation, and has been the recipient of many international awards and honors. 